\title{
TEMPERATURE-INITIATED STRUCTURAL CHANGES IN FeS 2 PYRITE FROM POHORJE, EASTERN ALPS, NORTH-EASTERN SLOVENIA
}

\author{
S TEMPERATURO POVZROČENE STRUKTURNE SPREMEMBE \\ $\mathrm{FeS}_{2}$ PIRITA IZ POHORJA, VZHODNE ALPE, SEVEROVZHODNA \\ SLOVENIJA
}

\author{
${ }^{1}$ Blaž Leskovar, ${ }^{2}$ Mirijam Vrabec, ${ }^{2}$ Matej Dolenec, ${ }^{1}$ Iztok Naglič, ${ }^{2}$ Tadej Dolenec, \\ ${ }^{3}$ Evgen Dervarič, ${ }^{1}$ Boštjan Markoli \\ ${ }^{1}$ University of Ljubljana, Faculty of Natural Sciences and Engineering, Department of Materials and Metallurgy, Ljubljana, Slovenia \\ ${ }^{2}$ University of Ljubljana, Faculty of Natural Sciences and Engineering, Department of Geology, Ljubljana, Slovenia \\ ${ }^{3}$ University of Ljubljana, Faculty of Natural Sciences and Engineering, Department of Mining and Geotechnology, Ljubljana, Slovenia \\ leskovarblaz@gmail.com
}

Prejem rokopisa - received: 2015-11-02; sprejem za objavo - accepted for publication: 2016-03-31

doi:10.17222/mit.2015.328

X-ray phase analysis (XRD), differential thermal analysis (DTA) and X-ray fluorescence spectroscopy (XRF) of pyrite samples in a protective (Ar) and an oxidative atmosphere (air) at different temperatures $(200,300,500,700){ }^{\circ} \mathrm{C}$ and times $(1,2,4) \mathrm{h}$ were made. A graphical representation of the unit cell of magnetic pyrrhotite and diffraction patterns of the individual crystal structures of pyrite, which occur in the sample at selected temperatures, atmosphere, and exposure times were analyzed with $\mathrm{X}$-ray diffraction software (CrystalMaker). The results show that $\mathrm{FeS}_{2}$ exhibited temperature-dependent changes in the crystal structure that are not included in current Fe-S phase diagrams.

Keywords: Pohorje, Eastern Alps, structural changes, FeS, pyrite, XRD, XRF, DTA

Vzorci pirita so bili analizirani s pomočjo rentgenske fazne analize (XRD), diferenčne termične analize (DTA) in rentgenske fluorescentne spektroskopije (XRF) po žarjenju v zaščitni (Ar) in oksidativni atmosferi (zrak) pri različnih temperaturah (200, 300, 500 in 700) ${ }^{\circ} \mathrm{C}$ in časih $(1,2$ in 4) h. S programsko opremo (CrystalMaker) je grafično predstavljena osnovna celica magnetnega pirotita. Analizirani so tudi rentgenogrami posameznih kristalnih struktur pirita, ki se pojavijo v vzorcu pri določenih temperaturah, atmosferi in časih žarjenja. Rezultati kažejo, da pirit izkazuje temperaturno odvisne spremembe $\mathrm{v}$ kristalni strukturi, ki niso vključene v dosedanje fazne diagrame Fe-S.

Ključne besede: Pohorje, Vzhodne Alpe, strukturne spremembe, pirit $\left(\mathrm{FeS}_{2}\right), \mathrm{XRD}, \mathrm{XRF}$, DTA

\section{INTRODUCTION}

Pyrite is the most common and widespread of the sulfide minerals, found in a wide variety of geological formations. It occurs as magmatic segregations, as an accessory mineral in igneous rocks, in contact metamorphic deposits, in large hydrothermal veins and in many sedimentary rocks. In these rocks the pyrite is usually found associated with other sulfides or oxides and is often mined for the gold or copper associated with it. Despite a high Fe content (46.55\% of mass fractions), pyrite has never been used as a significant source of iron. Because of the large amount of sulfur present in the mineral, it is used as an iron ore only in those countries where oxide iron ores are not available. Iron is produced from pyrite by roasting, causing complete oxidation and removal of the sulfur; the latter is the reason for the brittleness in iron and its alloys. ${ }^{1,2}$ During the early years of the 20th century, pyrite was used as a mineral detector in radio receivers, and is still used by 'crystal radio' hobbyists. Pyrite detectors occupied a midway point between galena detectors and the more mechanically complicated perikon mineral pairs. ${ }^{3,4}$ Pyrite is a semiconducting material with band gap of $0.95 \mathrm{eV} .^{5}$ It has been proposed as an abundant, inexpensive material in low-cost photovoltaic solar panels. ${ }^{6}$ Pyrite still remains in commercial use for the production of sulfur dioxide, in the paper industry, and in the production of sulfuric acid. It is also a source of sulfur, for the production of tires, explosives, disinfectants, medicines, ink, wood preservatives, dyes and matches. ${ }^{1}$ Pyrite is also used as the cathode material in the Energizer brand of non-rechargeable lithium batteries. ${ }^{7}$

Although pyrite is the principal constituent of many ore bodies, it is absent in some high-temperature deposits formed from liquids and gases, suggesting clear dependency of the pyrite crystallization under restricted temperature conditions. ${ }^{8}$ In this paper, the phase transformation of pyrite as a function of temperature, time and atmosphere are studied in order to clarify its stability and changes in crystal structure in the range of $33 \%$ of mass fractions to $60 \%$ of mass fractions of $\mathrm{S}$ in an inert atmosphere and the path of pyrite decomposition in the oxidative atmosphere. 
B. LESKOVAR et al.: TEMPERATURE-INITIATED STRUCTURAL CHANGES IN FeS 2 PYRITE ...

\section{GEOLOGICAL BACKGROUND AND SAMPLE LOCATIONS}

The Pohorje Mountains are located at the southeastern margin of the Eastern Alps in north-eastern Slovenia. They represent ultrahigh-pressure metamorphic terrane and are built up of three Eo-Alpine nappes that belong to pre-Neogene metamorphic sequences of Austroalpine units of the Eastern Alps. Structurally, the lowest nappe represents the Lower Central Austroalpine and consists of medium- to high-grade metamorphic rocks, predominantly micaschists, gneisses and amphibolites with marble and quartzite lenses. It also contains several eclogite lenses and a body of metaultrabasic rocks. The Pohorje nappe is overlain by nappe composed of weakly metamorphosed Paleozoic rocks, mainly lowgrade metamorphic slates and phyllites. The uppermost nappe is built up of Permo-Triasic clastic sedimentary rocks, mainly sandstones and conglomerates. The two latter nappes represent the Upper Central Austroalpine..$^{9,10}$ The entire nappe stack is overlain by Early Miocene sediments that belong to the svn-rift basin fill of the Pannonian Basin. ${ }^{11}$ The central part of Pohorje is occupied by granodioritic to tonalitic intrusion of Miocene age (18-19 Ma). ${ }^{12,13}$

Pyrite mines in Zgornja Polskava are located along the creek where several exploratory tunnels were dug in a sequence of metapelitic rocks. The GPS geographic coordinates of the mines are as follows: $\mathrm{N} 46^{\circ} 25^{\prime} 54.8^{\prime \prime}$, E $15^{\circ} 35^{\prime} 40.0$ '”.

Pyrite crystals occur within tremolite forming more than $50-\mathrm{cm}$-thick layers or veins in metapelitic country rocks. ${ }^{14,15}$ These are mostly gneisses and micaschists that formed under high-pressure and high-temperature conditions of $2.2-2.7 \mathrm{GPa}$ and $700-800{ }^{\circ} \mathrm{C}$. They are mediumgrained rocks with a granoblastic texture composed mostly of quartz, mica, biotite, garnet, kvanite, plagioclase and $\mathrm{K}$ feldspar. Metapelitic rocks in the investigated area are more or less intensively limonitized..$^{9,10,16}$

\section{FORMATION OF PYRITE AND SAMPLE DESCRIPTION}

The samples of pyrite that were used for the analyses were taken from the mine in Zgornja Polskava, which was operational from 1916 to 1920 . The ore was mainly used for the production of sulfuric acid. In abandoned mine tunnels, pyrite cubes from $2 \mathrm{~mm}$ to $20 \mathrm{~mm}$ in size and more can still be found today. ${ }^{15,17}$ From Figure $\mathbf{1}$ it is clear that analyzed samples are brass yellow modified cubes with typical pyrite striations on the surface. In places pyrite crystals are limonitized and contain rare quartz veins. The size of the samples is approximately $(20 \times 20 \times 20) \mathrm{mm}$.

Pyrite forms in high-temperature veins at temperatures from $300{ }^{\circ} \mathrm{C}$ to $400{ }^{\circ} \mathrm{C} .{ }^{16}$ The rock around the veins is characterized by a red color, which is due to the

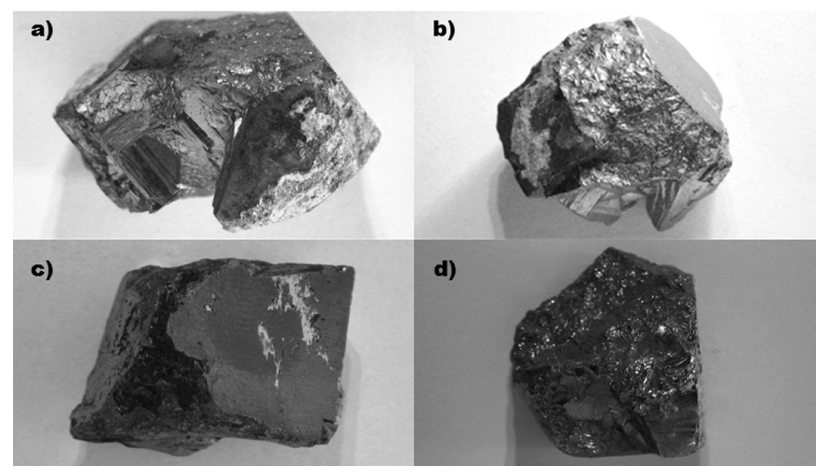

Figure 1: Analyzed samples of pyrite

Slika 1: Vzorci pirita uporabljeni za analize

presence of hematite dispersed in the sequence of metapelitic rocks. For hydrothermal ore deposits of this type it is characteristic that sulfides are found in the green, gray and black layers, which alternate with the red layer. $^{18}$

The binary phase diagram Fe-S reported by Kubaschewski ${ }^{19}$ is shown in Figure 2. The crystal structure of pyrite $(\alpha, \beta)$ transforms into the pyrrhotite $(\alpha, \beta, \gamma)$ when the sulfur concentration is decreasing or the temperature is rising. With increasing temperature the pyrite decomposes into pyrrhotite $(\gamma \mathrm{FeS})$ and liquid at a temperature of $743{ }^{\circ} \mathrm{C}$. Because of the low boiling point of sulfur $\left(444.6{ }^{\circ} \mathrm{C}\right)$ at atmospheric pressure the free bonded atoms evaporate (irreversible reaction). With decreasing temperature the crystal structures of $\gamma \mathrm{FeS}\left(\mathrm{P}_{3} / \mathrm{mmc}\right)$ transform to $\beta \mathrm{FeS}(\mathrm{P} \overline{6} 2 \mathrm{c})$ at $315{ }^{\circ} \mathrm{C}$ and then $\beta \mathrm{FeS}$ into $\alpha \mathrm{FeS}$ (unknown crystal structure by Kubaschewski).

\section{MATERIALS AND METHODS}

\subsection{X-ray powder diffraction (XRD)}

A Philips X-ray diffractometer with a PW3830 generator was used for the XRD analyses. The patterns were recorded with the following parameters: voltage $40 \mathrm{kV}$,

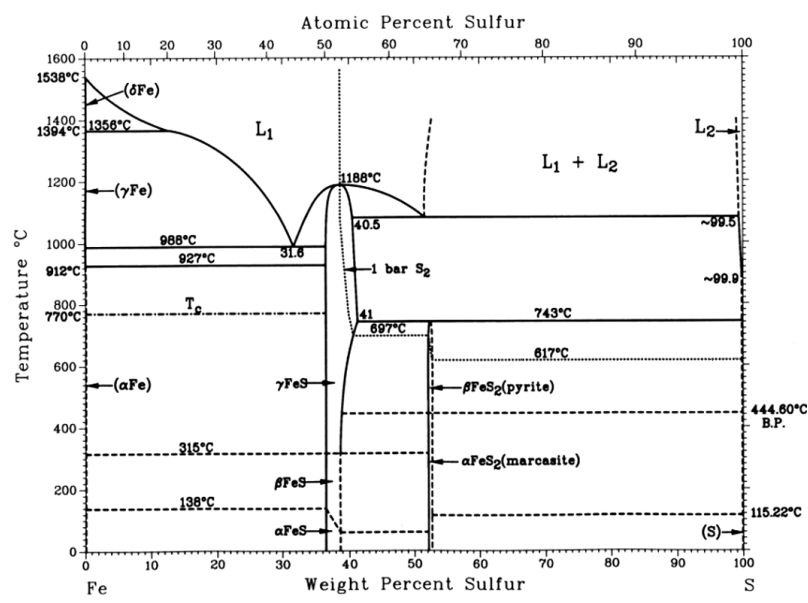

Figure 2: Phase diagram Fe-S ${ }^{19}$

Slika 2: Fazni diagram Fe-S ${ }^{19}$ 
current $30 \mathrm{~mA}$, wavelength of light used X-ray $\mathrm{Cu}-K \alpha$ $0.15418 \mathrm{~nm}$, secondary graphite monochromator and proportional counter. The angle $2 \theta$ was recorded in the range of $0^{\circ}$ to $70^{\circ}$, at a rate of $1.2^{\circ} 2 \theta / \mathrm{min}$. The limit of detection of the minerals in the sample is $1-3 \%$.

\subsection{X-ray fluorescent spectroscopy (XRF)}

A portable (field) X-ray fluorescence analyzer NITON (model XL3t + GOLDD-900S He) was used to determine the quantity of each element in the sample. The method allows a quantitative analysis of more than 80 elements, from magnesium to uranium. When measuring, we used the module "Mining". During the measurement the sampling site was pumped with helium gas for the better detection of light elements $(\mathrm{Mg}, \mathrm{Si}, \mathrm{Al}$, $\mathrm{P})$. The measurement time for each sample was $210 \mathrm{~s}$.

\subsection{Differential thermal analysis (DTA) and differen- tial scanning calorimetry (DSC)}

DSC was performed on a STA 449 Jupiter device by NETZSCH. All the analyses were carried out in a protective argon atmosphere or air. The experiments were conducted at heating/cooling rates of $10{ }^{\circ} \mathrm{C} / \mathrm{min}$, according to the Heat Flux mode. In this mode the investigative and comparative sample are heated with the same heat source.

\section{RESULTS AND DISCUSSION}

The phase transformations of pyrite are defined as a function of temperature, time and atmosphere. The crystal structures of the phases that occur in the sample at various temperatures and times in the presence of a protective (Ar) or the oxidizing atmosphere (air) were determined by means of X-ray structural analysis. The purity of each sample was identified using X-ray fluorescence spectroscopy. The presence of the chemical reactions or changes in the crystal structure was traced by DSC. The temperatures of the heating were $(300,500$

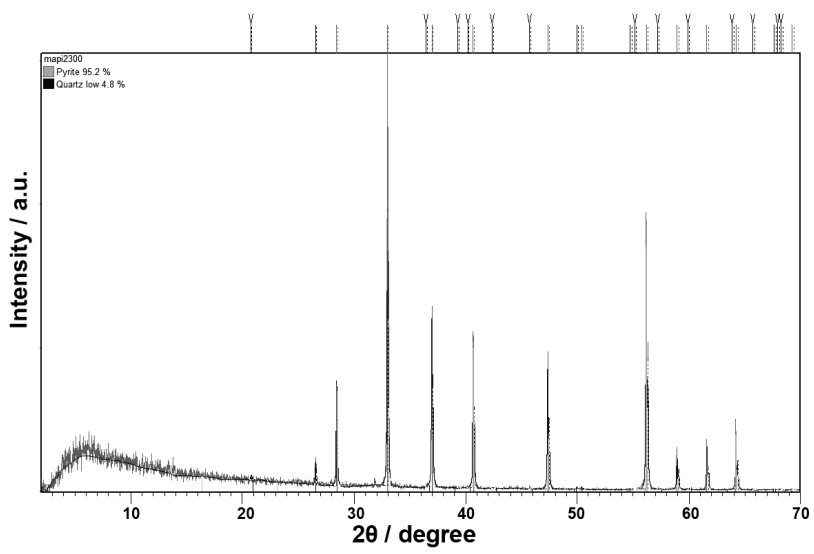

Figure 3: XRD analysis of a sample annealed at $300{ }^{\circ} \mathrm{C}$ for $4 \mathrm{~h}$ Slika 3: Rentgenogram vzorca žarjenega $4 \mathrm{~h}$ na temperaturi $300{ }^{\circ} \mathrm{C}$ and 700) ${ }^{\circ} \mathrm{C}$. At each temperature we held the samples for (1, 2 and 4$) \mathrm{h}$. The DSC experiments were carried out according to a temperature program of $10{ }^{\circ} \mathrm{C} \mathrm{min}-1$ to $800{ }^{\circ} \mathrm{C}$ to trace changes in $\mathrm{FeS}_{2}$ that were not found in $\mathrm{Fe}-\mathrm{S}$ phase diagram. The crystal structure of the sample was defined with the help of a computer program CrystalMaker and Atlas of Crystal Structure Types for Intermetallic Phases. ${ }^{20,21}$

\subsection{Annealing pyrite in air at $300{ }^{\circ} \mathrm{C}$}

In the crystal structure of pyrite no changes occurred after annealing at a temperature of $300{ }^{\circ} \mathrm{C}$ for $4 \mathrm{~h}$. The sample consisted of pyrite and quartz. The diffraction pattern for the sample after annealing at $300{ }^{\circ} \mathrm{C}$ for $4 \mathrm{~h}$ is shown in Figure 3.

The unit cell of pyrite is a cubic crystal lattice with a point symmetry by Hermann-Mauguin notation (HM) $m \overline{3}$ (there is mirror plane in the direction of $a$ and 3 -fold rotational axis with inversion $(\overline{3})$ in the direction of $b$ axis), and a space group $\mathrm{Pa} \overline{3}$, that illustrates the primitive lattices $(\mathrm{P})$, a glide plane in the direction of the $a$ axis and the 3 -fold rotational axis with the inversion $(\overline{3})$ in the direction of the $b$ axis. The unit cell of $\alpha$-quartz represents a trigonal crystal system with a point symmetry (HM) 32 (which illustrates the 3-fold axis in the direction of the $a$ axis and 2-fold rotational axis in the direction of the $b$ axis) and the space group $\mathrm{P}_{2} 21$ (primitive lattice $(\mathrm{P})$, the screw axis with the 3 -fold rotation in the direction of $a$ axis (triad) and a 2 -fold rotational axis in the direction of the $b$ axis).

\subsection{Annealing pyrite in air at $500{ }^{\circ} \mathrm{C}$}

Already after one hour of annealing at $500{ }^{\circ} \mathrm{C}$ a change in the crystal structure appeared. It can be seen that the intensity of the peaks representing the crystal structure of pyrite decreased (the amount of the crystalline structure of pyrite decreased) and new peaks arose, which represented new crystal structures. With the help of diffraction patterns it was found that along with the

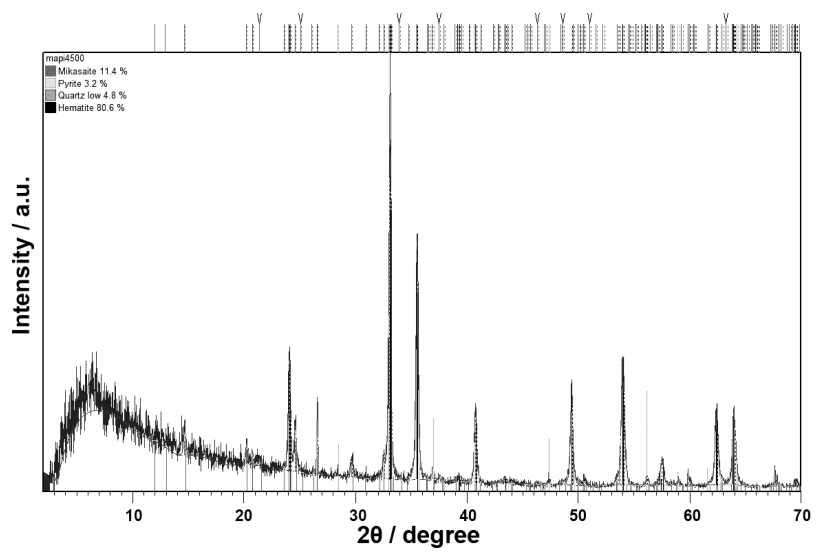

Figure 4: XRD analysis of a sample annealed at $500{ }^{\circ} \mathrm{C}$ for $4 \mathrm{~h}$ Slika 4: Rentgenogram vzorca žarjenega $4 \mathrm{~h}$ na temperaturi $500{ }^{\circ} \mathrm{C}$ 
crystal structure of pyrite and the quartz crystal structure of hematite $\left(\mathrm{Fe}_{2} \mathrm{O}_{3}\right)$ and mikasaite or iron(III)sulfate $\left(\mathrm{Fe}_{2}\left(\mathrm{SO}_{4}\right)_{3}\right)$ appeared. The amount of hematite increased with the annealing time, while the amount of pyrite and iron(III)sulfate decreased. The amount of quartz was equal during the time of annealing. Figure 4 has the diffraction pattern of a sample made after annealing at $500{ }^{\circ} \mathrm{C}$ for $4 \mathrm{~h}$.

The unit cell of the iron(III)sulfate belongs to the trigonal crystal system with a point symmetry (HM) $\overline{3}$ (3-fold rotation axis with inversion in the direction of $a$ axis), and a space group $R \overline{3}$ (rhombohedral lattice $\mathrm{R}$ and the 3 -fold rotation with the inversion in the direction of the $a$ axis). The basic cell of hematite ( $\alpha$-hematite) belongs to the trigonal crystal system with a symmetry point (HM) $\overline{3} 2 / m$ (which represents a 3 -fold rotational axis with the inversion in the direction of the $a$ axis and a 2 -fold rotational axis with the mirror plane in the direction of the $\mathrm{b}$ axis) and space group $R \overline{3} c$ (rhombohedral lattice $\mathrm{R}, 3$-fold rotation axis with inversion in the direction of the $a$ axis, and a glide plane in the direction of the $c$ axis).

\subsection{Annealing pyrite in air at $700{ }^{\circ} \mathrm{C}$}

Already after one hour of annealing at $700{ }^{\circ} \mathrm{C}$ the sample consisted of the crystal structure of hematite with only a small amount of quartz. The temperature was so high that the sulfur evaporated and reacted with the oxygen in the atmosphere to form sulfur dioxide. Oxygen from the atmosphere diffused into the sample and formed hematite. Figure 5 shows the diffraction pattern of the sample made after annealing at $700{ }^{\circ} \mathrm{C}$ for $4 \mathrm{~h}$.

\subsection{The X-ray fluorescent spectroscopy}

Table 1 presents the weight percentages of the chemical elements and the relative error in the calculation of weight fraction of the chosen elements. Presented are the three samples that were heated to $300{ }^{\circ} \mathrm{C}, 500{ }^{\circ} \mathrm{C}$ and $700{ }^{\circ} \mathrm{C}$ and exposed for $4 \mathrm{~h}$ to air.

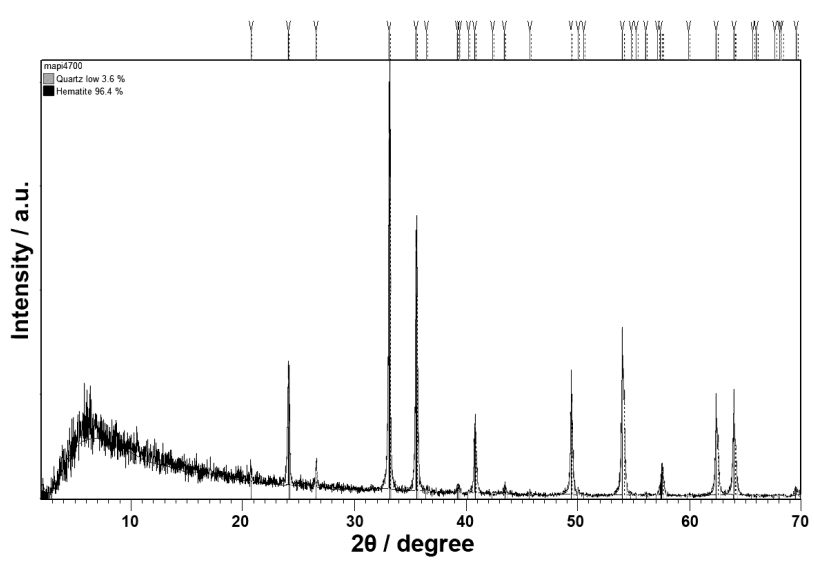

Figure 5: XRD analysis of a sample annealed at $700{ }^{\circ} \mathrm{C}$ for $4 \mathrm{~h}$ Slika 5: Rentgenogram vzorca žarjenega $4 \mathrm{~h}$ na temperaturi $700{ }^{\circ} \mathrm{C}$
The sample annealed at $300{ }^{\circ} \mathrm{C}$ had about $37 \%$ of mass fractions of $\mathrm{Fe}$, and approximately $60 \%$ of mass fractions of S. Due to the fact that the chemical composition of pyrite corresponds to $46.55 \mathrm{wt} \% \mathrm{Fe}$ and $53.45 \%$ of mass fractions of $\mathrm{S}$, it can be concluded that some atoms of sulfur are free and bonded to the surface of the sample. It can also be assumed that a small amount of tremolite $\mathrm{Ca}_{2} \mathrm{Mg}_{5} \mathrm{Si}_{8} \mathrm{O}_{22}(\mathrm{OH})_{2}$ is present (in which one can find pyrite) and some metamorphic rocks, specifically gneiss (location of exploratory tunnels of pyrite), due to the presence of other chemical elements.

Table 1: Chemical composition of samples annealed at $(300,500$ and 700) ${ }^{\circ} \mathrm{C}$ in air (X-ray fluorescent spectroscopy, w/\%)

Tabela 1: Kemična sestava vzorcev žarjenih na zraku pri temperaturah $(300,500$ in 700$){ }^{\circ} \mathrm{C}$ (rentgenska fluorescentna spektroskopija, w/\%)

\begin{tabular}{|c|c|c|c|c|c|c|}
\hline \multirow{2}{*}{$\begin{array}{c}\text { Tempe- } \\
\text { rature }\end{array}$} & \multicolumn{7}{|c|}{ Chemical element } \\
\cline { 2 - 7 } & Fe Error & $\mathrm{S}$ & $\mathrm{S}$ Error & $\mathrm{Si}$ & $\mathrm{Si}$ Error \\
\hline $300{ }^{\circ} \mathrm{C}$ & 37.49 & 0.14 & 60.77 & 0.13 & 0.01 & 0.02 \\
\hline $500^{\circ} \mathrm{C}$ & 53.72 & 0.46 & 17.63 & 0.11 & 4.37 & 0.05 \\
\hline $700{ }^{\circ} \mathrm{C}$ & 71.82 & 0.75 & 0.18 & 0.01 & 6.65 & 0.07 \\
\hline & $\mathrm{Al}$ & $\mathrm{Al}$ Error & $\mathrm{Ca}$ & $\mathrm{Ca}$ Error & $\mathrm{Cl}$ & $\mathrm{Cl}$ Error \\
\hline $300^{\circ} \mathrm{C}$ & 0.04 & 0.07 & 0.02 & 0.01 & 0.97 & 0.02 \\
\hline $500^{\circ} \mathrm{C}$ & 2.98 & 0.11 & 0.13 & 0.02 & 0.14 & 0.01 \\
\hline $700{ }^{\circ} \mathrm{C}$ & 1.03 & 0.06 & 0.19 & 0.02 & 0.23 & 0.01 \\
\hline & $\mathrm{Mg}$ & $\mathrm{Mg}$ Error & $\mathrm{P}$ & $\mathrm{P}$ Error & $\mathrm{As}$ & As Error \\
\hline $300{ }^{\circ} \mathrm{C}$ & 0.24 & 0.24 & 0.14 & 0.03 & 0.22 & 0.00 \\
\hline $500{ }^{\circ} \mathrm{C}$ & 0.94 & 0.22 & 0.13 & 0.02 & 0.33 & 0.01 \\
\hline $700{ }^{\circ} \mathrm{C}$ & 0.00 & 0.11 & 0.12 & 0.01 & 0.07 & 0.01 \\
\hline
\end{tabular}

\subsection{Differential scanning calorimetry (DSC)}

To determine the beginning of the phase transformations in air, differential scanning calorimetry was used. Figure 6 has a DSC heating curve for a run carried out using a heating/cooling rate of $10^{\circ} \mathrm{C} / \mathrm{min}$ on a sample of pure pyrite.

Pyrite was first transformed into an iron(III)sulfide, which then further dissociated into hematite. We believe that the disintegration process took place according to the following chemical reactions in Equations (1), (2) and (3):

$$
2 \mathrm{FeS}_{2}(\mathrm{~s})+7 \mathrm{O}_{2}(\mathrm{~g}) \rightarrow \mathrm{Fe}_{2}\left(\mathrm{SO}_{4}\right)_{3}(\mathrm{~s})+\mathrm{SO}_{2}(\mathrm{~g})
$$

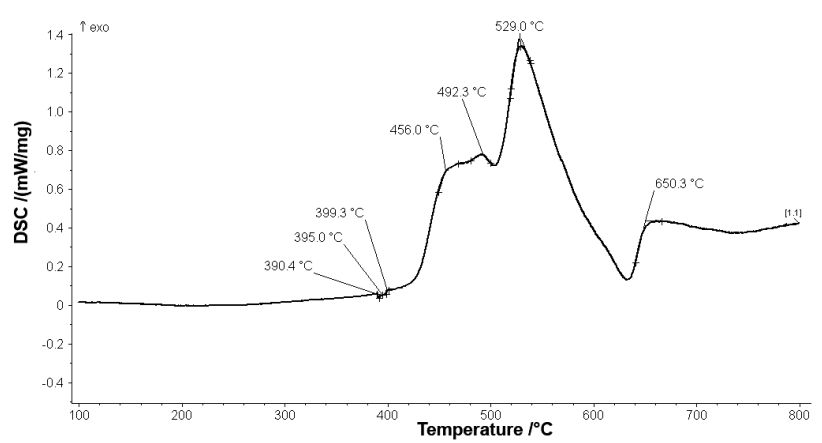

Figure 6: DSC heating curve for pyrite in air Slika 6: DSC-krivulja segrevanja pirita na zraku 


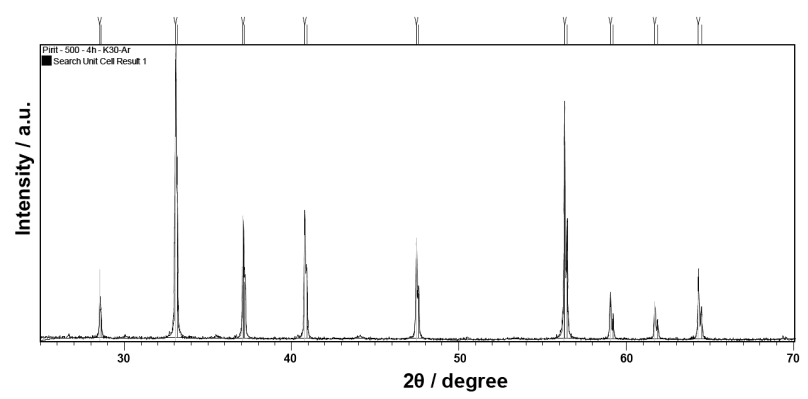

Figure 7: XRD analysis of a sample annealed at $500{ }^{\circ} \mathrm{C}$ for $4 \mathrm{~h}$ Slika 7: Rentgenogram vzorca žarjenega $4 \mathrm{~h}$ na temperaturi $500{ }^{\circ} \mathrm{C}$

$$
\begin{gathered}
\mathrm{Fe}_{2}\left(\mathrm{SO}_{4}\right)_{3}(\mathrm{~s}) \leftrightarrow \mathrm{Fe}_{2} \mathrm{O}_{3}(\mathrm{~s})+3 \mathrm{SO}_{3}(\mathrm{~g}) \\
\mathrm{SO}_{2}(\mathrm{~g})+0,5 \mathrm{O}_{2}(\mathrm{~g}) \leftrightarrow \mathrm{SO}_{3}(\mathrm{~g})
\end{gathered}
$$

Apparently, the disintegration of iron(III)sulfide is obviously complicated as it involves three partial reactions. So, the total rate of disintegration or conversion of iron(III)sulfide into hematite depends on the partial rate of each individual reaction listed above.

\subsection{Annealing pyrite in a protective atmosphere (argon) at $200{ }^{\circ} \mathrm{C}, 300{ }^{\circ} \mathrm{C}$ and $500{ }^{\circ} \mathrm{C}$}

Annealing in a protective atmosphere at $500{ }^{\circ} \mathrm{C}$ does not lead to the transformation of pyrite. The Figure 7 shows a diffraction pattern of a sample after annealing at $500{ }^{\circ} \mathrm{C}$ for $4 \mathrm{~h}$.

\subsection{Annealing pyrite in a protective atmosphere (argon) at $700{ }^{\circ} \mathrm{C}$}

Already after one hour of sample annealing at $700{ }^{\circ} \mathrm{C}$ it can be observed that the crystalline structure of pyrite transformed to the magnetic pyrrhotite $\mathrm{Fe}_{7} \mathrm{~S}_{8}$. Figure 8 has a diffraction pattern of magnetic pyrrhotite and the corresponding unit cell as generated by CrystalMaker. Additionally, there is the diffraction pattern of a sample made after annealing at $700{ }^{\circ} \mathrm{C}$ for $4 \mathrm{~h}$.

The basic cell of magnetic pyrrhotite $\mathrm{Fe}_{7} \mathrm{~S}_{8}$, Figure $\mathbf{8 c}$, belongs to the trigonal crystal system, point group (HM) $\overline{3}$ (3-fold axis with the inversion in the direction of the $a$ axis), and the space group $R \overline{3}$ (rhombohedral lattice $\mathrm{R}$, and the 3 -fold axis with the inversion in the direction of the $a$ axis).

\subsection{The X-ray fluorescent spectroscopy (argon)}

Table 2 presents the weight percentages of chemical elements and the relative error in the calculation of the weight fraction of each element. Presented are the three samples that were heated to $(300,500$ and 700$){ }^{\circ} \mathrm{C}$ and exposed for $4 \mathrm{~h}$ in argon.

Table 2: Chemical composition of samples annealed at (300, 500 and $700){ }^{\circ} \mathrm{C}$ in argon (X-ray fluorescent spectroscopy, w/\%)

Tabela 2: Kemijska sestava vzorcev žarjenih v zaščitni atmosferi (Ar) pri temperaturah $300{ }^{\circ} \mathrm{C}, 500{ }^{\circ} \mathrm{C}$ in $700{ }^{\circ} \mathrm{C}$ (rentgenska fluorescenčna spektroskopija, w/\%)

\begin{tabular}{|c|c|c|c|c|c|c|}
\hline \multirow{2}{*}{$\begin{array}{c}\text { Tempe- } \\
\text { rature }\end{array}$} & \multicolumn{7}{|c|}{ Chemical element } \\
\cline { 2 - 7 } & $\mathrm{Fe}$ & Fe Error & $\mathrm{S}$ & $\mathrm{S}$ Error & $\mathrm{Si}$ & Si Error \\
\hline $300{ }^{\circ} \mathrm{C}$ & 35.47 & 0.03 & 32.25 & 0.02 & 0.71 & 0.07 \\
\hline $500^{\circ} \mathrm{C}$ & 35.41 & 0.07 & 32.12 & 0.01 & 0.78 & 0.11 \\
\hline $700{ }^{\circ} \mathrm{C}$ & 47.18 & 0.02 & 23.29 & 0.02 & 2.98 & 0.07 \\
\hline & $\mathrm{Al}$ & $\mathrm{Al}$ Error & $\mathrm{Ca}$ & $\mathrm{Ca}$ Error & $\mathrm{Cl}$ & $\mathrm{Cl}$ Error \\
\hline $300^{\circ} \mathrm{C}$ & - & 0.07 & 0.02 & 0.07 & 0.04 & 0.06 \\
\hline $500^{\circ} \mathrm{C}$ & 0.16 & 0.13 & 0.02 & 0.03 & 0.05 & - \\
\hline $700{ }^{\circ} \mathrm{C}$ & 0.33 & 0.03 & 0.07 & 0.05 & 0.05 & - \\
\hline & $\mathrm{Cr}$ & $\mathrm{Cr}$ Error & $\mathrm{Mg}$ & $\mathrm{Mg}$ Error & $\mathrm{As}$ & $\mathrm{As} \mathrm{Error}$ \\
\hline $300^{\circ} \mathrm{C}$ & 0.02 & 0.00 & - & 0.09 & 0.08 & - \\
\hline $500{ }^{\circ} \mathrm{C}$ & 0.02 & 0.00 & 0.88 & 0.05 & 0.08 & 0.00 \\
\hline $700{ }^{\circ} \mathrm{C}$ & 0.03 & 0.00 & 0.01 & 0.00 & 0.00 & 0.00 \\
\hline
\end{tabular}

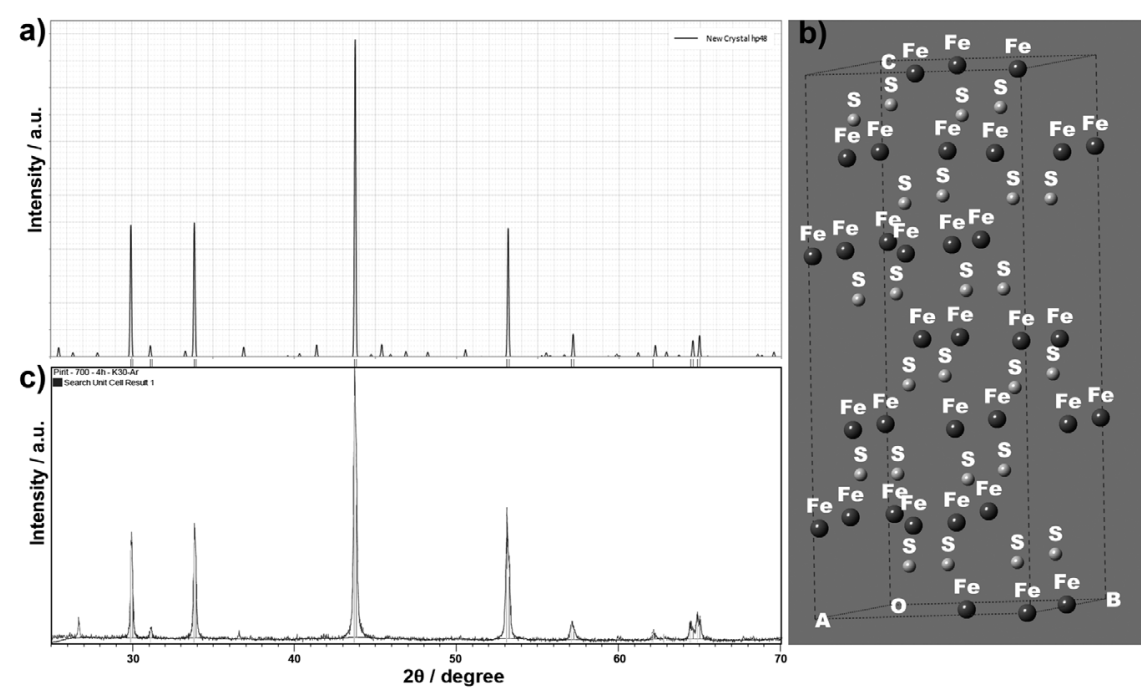

Figure 8: XRD analysis of a sample annealed at $700{ }^{\circ} \mathrm{C}$ for $4 \mathrm{~h}$ : a) diffraction pattern of magnetic pyrrhotite, b) with its unit cell and c) the diffraction pattern of the sample

Slika 8: Rentgenogram vzorca žarjenega $4 \mathrm{~h}$ pri temperaturi $700{ }^{\circ} \mathrm{C}$ : a) generiran rentgenogram magnetnega pirotita, b) z osnovno celico in c) rentgenogram žarjenega vzorca 


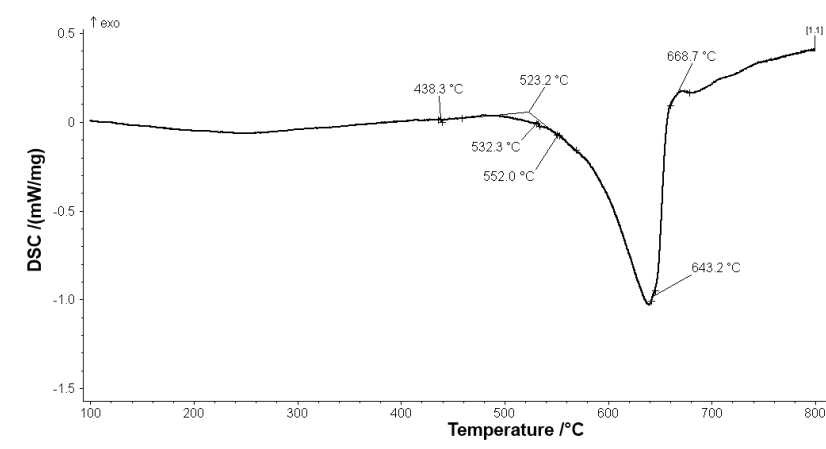

Figure 9: DSC heating curve of pyrite in argon

Slika 9: DSC-krivulja segrevanja pirita v zaščitni atmosferi (Ar)

As can be seen from Table 2, we have a sample of about 35 wt. $\%$ of Fe and about 32 wt. \% of S. Since the $\mathrm{X}$-ray fluorescence spectroscopy cannot detect light chemical elements, from $\mathrm{H}$ to $\mathrm{Na}$, these could have not been analyzed. Hence, the mass percentages of the remaining chemical elements do not sum up $100 \mathrm{wt}$ \% The difference can be attributed to the presence of light elements.

\subsection{Differential scanning calorimetry (DSC)}

To determine the beginning of the phase transformations in a protective atmosphere we again turned to differential scanning calorimetry. In Figure 9 the DSC heating curve for the sample of pyrite was carried out using a temperature program of $10^{\circ} \mathrm{C} / \mathrm{min}$ in argon.

From the heating DSC curve we can see that the change in the crystalline structure of pyrite $(\mathrm{Pa} \overline{3})$ into the magnetic pyrrhotite $(R \overline{3})$ started at about $530{ }^{\circ} \mathrm{C}$. The transformation of pyrite in a protective atmosphere takes place according to the following chemical reaction in Equation (4):

$$
7 \mathrm{FeS}_{2}(\mathrm{~s}) \leftrightarrow \mathrm{Fe}_{7} \mathrm{~S}_{8}(\mathrm{~s})+3 \mathrm{~S}_{2}(\mathrm{~g})
$$

\section{CONCLUSIONS}

Based on the results of the X-ray fluorescence spectroscopy, X-ray phase analysis and differential thermal analysis, we can conclude the following:

- The largest amount of impurities in the pyrite samples was represented by quartz and some heavier elements, but these were present with a very low content.

- The process of pyrite decomposition in the oxide atmosphere depends heavily on the temperature.

- The transformation of pyrite at a temperature of 500 ${ }^{\circ} \mathrm{C}$ takes place gradually by the formation of iron(III)sulphate, which is further oxidized into the crystal structure of hematite.

- At a temperature of $700{ }^{\circ} \mathrm{C}$ and the oxidizing atmosphere pyrite directly decomposed into hematite after only $1 \mathrm{~h}$.

- The result of the dissolution of pyrite in a protective atmosphere is the formation of magnetic pyrrhotite
$\mathrm{Fe}_{7} \mathrm{~S}_{8}$. Direct transformation occurred already after $1 \mathrm{~h}$ of annealing at $700{ }^{\circ} \mathrm{C}$.

- Finally, we established that pyrite is not stable up to $744{ }^{\circ} \mathrm{C}$, as predicted by the $\mathrm{Fe}-\mathrm{S}$ phase diagram, but rather undergoes changes into magnetic pyrrhotite.

\section{Acknowledgement}

I would like to thank all in the Dept. of Materials and Metallurgy and the Dept. of Geology who helped me in this project, especially in the preparation of samples and the interpretation of results.

\section{REFERENCE}

${ }^{1}$ T. Rosenqvist, Principles of extractive metallurgy, Tapir academic press, 2004

${ }^{2}$ B. Leskovar, B. Markoli. Spremembe kristalne strukture z?elezovega disulfida $\mathrm{s}$ temperaturo $=$ Change in crystal structure of iron disulphide with temperature: diplomsko delo, Ljubljana, 2013

${ }^{3}$ T. H. Lee, The Design of CMOS Radio-Frequency Integrated Circuits, Cambridge University Press, 2004, 4-6

${ }^{4}$ United States Army Signal Corps, Radio Communication Pamphlet, U.S. Government Printing Office, 1919, 302-305

${ }^{5}$ T. H. Ellmer K., Iron Disulfide (Pyrite) as Photovoltaic Material: Problems and Opportunities, Proceedings of the 12th Workshop on Quantum Solar Energy Conversion - (QUANTSOL) 2000

${ }^{6}$ C. Wadia, A. P. Alivisatos, D. M. Kammen, Materials availability expands the opportunity for large-scale photovoltaics deployment, Environmental Science \& Technology, 43 (2009) 6, 2072-7, doi:10.1021/es8019534

${ }^{7}$ Energizer Corporation, Lithium Iron Disulfide Handbook and Application Manual. Energizer Battery Manufacturing Inc., http://www.ruedespiles.com/images/PDFmedia/Fiche_technique_ Pile_ENERGIZER_LR6_AA_Lithium.pdf, 28. 10. 2015

${ }^{8}$ G. Kullerud, H. S. Yoder, Pyrite stability relations in the Fe-S system, Economic Geology, 54 (1959) 4, 533-72, doi:10.2113/ gsecongeo.54.4.533

${ }^{9}$ M. Janák, N. Froitzheim, B. Lupták, M. Vrabec, E. J. K. Ravna, First evidence for ultrahigh-pressure metamorphism of eclogites in Pohorje, Slovenia: Tracing deep continental subduction in the Eastern Alps, Tectonics, 23 (2004) 5, 1-10, doi:10.1029/ 2004TC001641

${ }^{10}$ M. Janak, N. Froitzheim, M. Vrabec, E. Krogh Ravna, J. Hoog, Ultrahigh-pressure metamorphism and exhumation of garnet peridotite in Pohorje, Eastern Alps, Journal of metamorphic Geology, 24 (2006) 1, 19-31, doi:10.1111/j.1525-1314.2005.00619.x

${ }^{11}$ L. Fodor, K. Balogh, I. Dunk1, Z. Pécskay, B. Koroknai, M. Trajanova, et al., Structural evolution and exhumation of the Pohorje-Kozjak Mts., Slovenia, Annales Universitatis Scientarum Budapestinensis, Sectio Geologica, $35 \quad$ (2003) 118-9, doi:10.2478/v10096-010-0027-y

${ }^{12}$ N. Zupančič, Petrografske značilnosti in klasifikacija pohorskih magmatskih kamnin, Rudarsko-metalurški zbornik, 12 (1994) 101

${ }^{13}$ M. Trajanova, Z. Pecskay, T. Itaya, K-Ar geochronology and petrography of the Miocene Pohorje Mountains batholith (Slovenia), Geologica carpathica 59 (2008) 3, 247

${ }^{14}$ D. Preisinger, A. Novak, M. Jeršek, M. Chvatal, Rudniki : opuščeni rudniki v Sloveniji, Turistika, Golnik (2010), 122-123

${ }^{15}$ Pajtler F., Minerali občin Slovenska Bistrica in Oplotnica (nahajališče Janezov graben pri Polskavi), Zavod za kulturo Slovenska Bistrica, Slovenska Bistrica, (2003) 33-7

${ }^{16}$ R. Vidrih, M. Grm, Svet mineralov, Tehniška založba Slovenije, Ljubljana, 2002, 6-42

${ }^{17}$ F. Tućan, Mineralogija: Specijalna mineralogija, Školska knjiga, 1957, 8-10, 118-121 


\section{MATERIALI IN TEHNOLOGIJE/MATERIALS AND TECHNOLOGY (1967-2017) - 50 LET/50 YEARS}

B. LESKOVAR et al.: TEMPERATURE-INITIATED STRUCTURAL CHANGES IN FeS 2 PYRITE ...

${ }^{18}$ J. Zavašnik, T. Dolenec, A. Rečnik. Nahajališče pirita pri Katarini nad Ljubljano $=$ Pyrite occurance close to Katarina mountain near Ljubljana, 2009

${ }^{19} \mathrm{H}$. Okamoto, Phase diagrams of binary iron alloys, ASM International, 1993

${ }^{20}$ CrystalMaker Software Limited Centre for Innovation and Enterprise, Oxford University Begbroke Science Park, http://www.crystalmaker.com/, 20. 10. 2015

${ }^{21}$ J. L. C. Daams, P. Villars, J. H. N. Vucht, Atlas of Crystal Structure Types for Intermetallic Phases, ASM International, 1991 